\title{
Nigeria And Her Immediate Neighbours In The Post Colonial Era: A Critical Analysis
}

\author{
Barr. Solomon Ogbu \\ Professor, Department Of Political Science And International Relations \\ University Of Abuja
}

Osunyikanmi Pius Olakunle, Ph.D

Ministry Of Foreign Affairs, Abuja

\begin{abstract}
The paper provides a lucid analysis of Nigeria's relationship with her immediate neighbours with a view to understanding the nature of her foreign policy towards the neighbouring countries. Nigeria has land borders with the Republics of Niger, Chad, Benin, and Cameroun, and also has maritime borders with the Republics of Benin, Chad, Cameroun, Equatorial Guinea, and Sao Tome and Principe. It is clear from the available literature that Nigeria has good diplomatic relations with her immediate neighbours, albeit occasional border disputes which are often resolved amicably. It is recommended that as the most populous, most economically powerful, and most militarily powerful nation among the immediate neighbours, it is advisable for Nigeria to maintain good relations with her neighbours for the sake of her national interest.
\end{abstract}

Keywords: National interest, Border disputes, concentric cycle, Foreign policy objectives, Good neighbourliness.

\section{INTRODUCTION}

The nature of a country's bilateral and multilateral relations with other countries and international organizations determine how the country is regarded and treated in the international community. No country can survive or prosper in isolation as no country is an island self-sufficient in everything. Therefore, peaceful co-existence and cooperation with both remote and immediate neighbours cannot be treated with levity by any country that desires to achieve her foreign policy objectives, especially the desire to achieve greatness and relevance within and beyond the country's immediate geographical environment. This point is particularly relevant and important to Nigeria which is playing a leadership role in West Africa and in the larger continent of Africa.

It is against this background that a critical analysis of Nigeria's relations with her immediate neighbours is a worthwhile exercise. Accordingly, the analysis in this paper focuses on Nigeria's relations with the Republic of Benin, Republic of Cameroun, Republic of Chad, the Republic of Equatorial Guinea, and the Republic of Niger. This exercise is intended to provide a platform for assessing the nature of Nigeria's relations with her neighbours since her independence in 1960.

\section{Understanding Nigeria's Neighbourhood}

Nigeria is located in the West Coast of Africa along the Atlantic Ocean. It lies in latitude $10^{\circ} 00$ North of the Equator, and longitude $8^{\circ} 00$ East of the Greenwich Meridian. The country shares land borders with the Republic of Benin (measuring 109 kilometre long), Cameroon (measuring 10975 kilometre long), Chad (measuring 85 kilometre long), and Niger (measuring 
1,608 kilometre long). It shares littoral boundaries with the Republic of Benin, Cameroon, Chad, Equatorial Guinea, Ghana, Togo and Sao Tome and Principe. Recent head counts show that these countries have the following population figures respectively:

$\begin{array}{llll}\text { (i) } & \text { Republic of Benin } & : & 11.04 \text { million } \\ \text { (ii) } & \text { Cameroon } & : & 24.99 \text { million } \\ \text { (iii) } & \text { Chad } & : & 7.93 \text { million } \\ \text { (iv) } & \text { Equatorial Guinea } & : & 777.358 \text { thousand } \\ \text { (v) } & \text { Ghana } & : & 28.83 \text { million } \\ \text { (vi) } & \text { Niger } & : & 19.25 \text { million } \\ \text { (vii) } & \text { Sao Tome and Principle } & : & 201,025 \text { thousand } \\ \text { (viii) } & \text { Togo } & : & 7.93 \text { million }\end{array}$

Nigeria has the following features:

$\begin{array}{lll}\text { Population } & : & 186,053,386 \text { (recent estimate) } \\ \text { Land Area } & : & 910,768 \mathrm{~km}^{2} \\ \text { Water Area } & : & 13,000 \mathrm{~km}^{2} \\ \text { Total Area } & : & 923,768 \mathrm{~km}^{2}\end{array}$

In the light of the population figures of Nigeria's immediate neighbours, Nigeria is, apart from her relative economic strength, overwhelmingly the most populous country among her immediate neighbours. This is in addition to the possession of a disproportionately big chunk of other elements of state power all which make Nigeria the regional power in West Africa and the rest of Africa. On the whole, Nigeria is surrounded by relatively weak neighbours.

One stark reality that stares at us in the face is that with the exception of Equatorial Guinea which was a Spanish colony, all the other immediate neighbours of Nigeria were colonized by France and still enjoy linguistic, cultural, political, economic, and even military affinities and cooperation with France. Thus, being the only English speaking country in the mist of countries that are still under French influence, Nigeria has no choice but to tread warily in her dealings and transactions with these countries. The fact that Nigeria is surrounded by French speaking immediate neighbours coupled with the fact that the delineation of the artificial boundaries between her and the other countries without taking cognizance of their ethnic and historical realities have continued to plague Nigeria's relations with her immediate neighbours.

The arbitrary border demarcations in Africa by the European powers at the Berlin Conference between 1884 and 1885 sowed the seed of discord and perennial border disputes among African countries. This is instrumental to the incessant border disputes between Nigeria and her immediate neighbours since after the departure of the colonial masters in the early 1960s. According to Andemichael (1976), disputes arising from artificial international boundaries in Africa exhibit the following characteristics:

(i) Occurrence of disputes between sovereign states;

(ii) Escalation of disputes into armed conflict - becoming a particular concern to both the UN and the defunct OAU (now African Union).

(iii) Involvement of claims by one party or the other on historical, cultural, ethnic or religious grounds to a segment of the territory presently under the jurisdiction of the other, a claim which the latter party regards as a threat to its sovereignty and territorial integrity.

Inter-state disputes arising from claims and counter-claims over the international boundaries arbitrarily drawn by the European powers, as highlighted above, can be classified into four categories (Prescott, 1965): 


\section{Territorial Disputes:}

This arises from controversy over which state has the right of ownership to a particular piece of territory;

\section{Positional Disputes}

This involves disagreement over the interpretation of documents describing the position of a boundary.

\section{Functional Disputes}

This concerns question of whether or not a state should extend her customs and immigration control beyond her territory; and

\section{Disputes over resource development}

Unfortunately, the features of all the above four categories of inter-state boundaries in Africa apply to Nigeria, while the first and second categories cut across virtually all African countries, especially where disagreements and negotiation had begun before the compilation of mutually agreed maps and records (Muir, 1983). On the whole, inter-state boundary disputes among African countries in post-colonial Africa are pervasive and have in many cases defied solution despite the intervention of institutional mechanism to deal with the problem.

Nonetheless, Nigeria has over the years been able to weather the storm of overt and covert threats to her territorial integrity by leveraging on her much celebrated principle of good neighbourliness and preventive diplomacy. In this way, Nigeria has been able to diffuse and resolve most outstanding boundary disputes between her and her immediate neighbours, including her protracted dispute with Cameroon over the Bakassi Peninsular which was eventually put to rest following the judgement of the International Court of Justice (ICT) which on October 10, 2002 ceded the Peninsular to Cameroon.

Nigeria's policy of good neighbourliness encompasses her principle of sovereign equality of all states, big or small, and the principle of non-interference in the internal affairs of other states. To this end, West Africa occupies the first and innermost position in Nigeria's concept of three concentric circles. The application of this concept in Nigeria's foreign policy formulation and implementation has gone a long way in helping to ensure cordial relations with her immediate neighbours and the whole of West Africa. Consistent with this, Nigeria does not harbour territorial ambition that would put her on a collusion course with her immediate neighbours.

\section{Principles of Nigeria's Foreign Policy and National Interest The National Interests}

Like every other country, the objectives and principles of Nigeria's foreign policy are anchored on the country's core and peripheral national interests. Nigeria's core national interest consists of:

(i) The protection of the territorial integrity, sovereignty and independence of the country

(ii) The utilization of the country's human and natural resources for the promotion of the material well-being of the Nigerian citizens

(iii) Projecting the status and image of the country in the international community.

Part of Nigeria's peripheral national interest include:

(i) The restoration of human dignity to black men and women all over the world, particularly the eradication of all supremacist regimes and colonial vestiges in all parts of Africa 
(ii) The preservation of the territorial integrity and security of all African countries

(iii) The promotion of world peace and justice.

\section{Objectives of Nigeria's Foreign Policy}

Foreign policy as defined by Northedge (1968) is simply an interplay between the outside and the inside. For Frankel (1975), foreign policy is a dynamic process of interaction between the changing domestic demands and supports and the changing international environment.

Section 19 of the 1999 Constitution categorically states the broad outline of the objectives of Nigeria's foreign policy as follows:

(i) Promotion and protection of the country's national interest;

(ii) Promotion of African integration and support for African unity;

(iii) Promotion of international cooperation for the consolidation of universal peace and mutual respect among all nations and elimination of discrimination in all its ramifications;

(iv) Respect for international law and treaty obligations as well as the seeking of settlement of international disputes by negotiation, mediation, conciliation, arbitration and adjudication; and

(v) Promotion of a just world economic order.

\section{Principles of Nigeria's Foreign Policy}

The principles underlying Nigeria's foreign policy were clearly spelt out at independence under the government of the first Prime Minister of Nigeria, Alhaji Abubakar Tafawa Balewa, and have since then been fully established and complied with as a tradition by successive governments of the country. These are as follows: (Olusanya, G. and Akindele, R., p.1986:2-4)

(i) Non-alignment (the cold war that necessitated this was between 1947 and 1991)

(ii) Legal equality of states

(iii) Non-interference in the domestic affairs of other states

(iv) Functional cooperation (multilaterialism)

(v) Africa as the centre-piece of the country's foreign policy

\section{Nature of Nigeria's Relations with Her Immediate Neighbours}

As indicated earlier in the paper, two fundamental issues are instrumental to the nature of Nigeria's relations with her immediate neighbours, namely:

(i) The fact that Nigeria is surrounded by Francophone countries which are still disposed to France's values and orientation; and

(ii) The fact that the artificial boundaries that were imposed on these countries without taking cognizance of ethnic and historical affinities are still generating conflicts and animosity among neighbouring countries in West Africa as in the rest of Africa.

Nevertheless, successive governments of Nigeria have always tried to conduct the country's relations with her immediate and distant neighbours within the framework of the declared principles of the country's foreign policy.

\section{NIGERIA - REPUBLIC OF BENIN}

Relations between the two countries can be said to be generally cordial but sometimes marred by occasional outbursts of border clashes. This is usually caused by Beninese gendarmes who forcefully collect taxes from Nigerians who reside along the Nigeria-Benin border villages, and sometimes go to the extent of removing the Nigerian flag at the border as a way of laying claim to the ownership of the area. In view of this, Ate and Akinterinwa (1992) assert that the 
authorities of the Beninese at the border constitute serious security threats to Nigeria. As they put it:

The security relations between Nigeria and Benin have always centred on two issue areas - boundary and military relations. The two overlap. Boundary relations are important in the first place because of the imprecision which marked the delimitation exercise... This setting is further compounded by the activities of smugglers and the actions of overzealous functionaries who attempt to enforce legislation beyond their areas of jurisdiction... Besides boundary relations, political instability especially in Benin Republic has been important for their security relations.

Besides, in trying to enhance her combat readiness in the event of invasion by Nigeria, Benin often acquires sophisticated weapons to deter Nigeria. The Republic of Benin did not show sympathy to the Federal Government of Nigeria during the Nigerian civil war between 1967 and 1970. During the period, there were indications that the Republic of Benin under President Emile Zinsou allowed her territory to be used as a staging post by the International Red Cross Committee and other Relief Organizations and even French Mercenaries for airlifting relief materials and weapons to Biafra. The activities of these organizations tended to undermine the food blockade imposed on Biafra by the federal government of Nigeria. All this triggered series of hostilities and border clashes between Nigeria and the Republic of Benin (Aluko, 1977). However, the signing of a Military Cooperation Agreement between the two countries in April 1979 put much of the lingering threats and distrust to rest, and this paved way for rapprochement and normal diplomatic relations between the two neighbours.

However, certain trans-border activities between the two countries remain a source of threat to the national security of Nigeria. These include uncontrolled smuggling of petroleum products and other essential commodities such as sugar, beverages, textiles and detergents by Beninese citizens who also engage in piracy along the creeks and swamps that lie between Nigeria and Benin. Besides, the Nigeria-Benin porous borders serve as an escape route for Nigerian fugitives, fleeing Nigerian criminals like car snatchers, notorious armed robbers, and Nigerian politicians who have looted government treasures and are running away to escape justice. In addition, the problem of illegal aliens in both countries who at different points in time have been repatriated by the government of each country has often times reduced diplomatic relations between the two countries to a low ebb. However, the endemic problem in the relationship between Nigeria and the Republic of Benin is the French factor. There is a military pact between France and the Republic of Benin and on the strength of this, France has continued to supply sophisticated weapons to Benin at subsided prices. This and the fact that France will be ready to render military assistance to Benin in the event of a war with Nigeria remain a potential danger to Nigeria's national security.

However, genuine efforts have been made in recent years by the governments of both countries to improve and strengthen bilateral relations between themselves. The effect of that is palpable in the renewed relations between the two countries. For example, there has been an astronomical increase in trade and commerce between the two countries, there has been a phenomenal increase in the number of joint ventures between the two countries; there is now a joint immigration and customs patrol and services at the borders; there is an express road that facilitates free movement of persons, goods and services between the two countries; and most importantly, there is now military cooperation between both countries, facilitated by the April 1979 military cooperation Agreement between both of countries. Elated by all this development, a top Nigerian government functionary said:

Friction along the two countries' borders had considerably reduced as a result of bilateral meetings held at various governmental levels... Increased cooperation 
between Benin and Nigeria has led to fruitful joint efforts in policing the border, e.g. armed robbers and car snatchers find it difficult to dispose of stolen goods (Shagaya, 1990).

\section{NIGERIA - CAMEROUN}

There can be no gainsaying the fact that diplomatic relations between Nigeria and Cameroun has been largely chequered, swinging from one end to the other like a pendulum. This, needless to say, was until recently as a result of the age-long dispute over the ownership of the Bakassi Peninsular on which the International Court of Justice (ICJ) in October 2002 delivered a judgement to settle.

According to Vogt (1987a), "the boundary (Nigeria-Cameroun) is the longest of all Nigeria's international boundaries and is the most complicated topographically". The complicated nature of the boundary gave rise to constant violent border disputes with far-reaching consequences for bilateral relations between two countries (Ate and Akinterinwa, 1992).

The location of the Bakassi Peninsula is described thus:

The Peninsular is located at the South Eastern tip of Nigeria, where the Peninsular pushes southward into the Gulf of Guinea. It is a low-lying region bordered on the West by the estuary of the Cross River, on the North by the Akpa Yafe (also known the Akpa Ikang), on the East by the Riodel esturary, and on the South by the Gulf of Guinea. The Peninsular itself consists of series of islands covering approximately 50 square kilometers and occupied for the most part by long established communities of Nigerians, in several dozen villages (The Federal Government of Nigeria 1996).

Cameroun has always supported her claim to the ownership of Bakassi Peninsular with two major factors, namely; (1) the 1913 Ango-German Treaty (signed between Britain and Germany in that year), and (2) the 1975 Maroua Declaration by which the then head of the military government of Nigeria, General Yakubu Gowon, purportedly agreed to cede the Peninsular to Cameroun. The Anglo-German Treaty, according to the Federal Government of Nigeria (1996) was meant to:

(a) Rearrange the boundary between Nigeria and Cameroun from Yola to the Sea;

(b) Regulate the navigation of the Cross River.

The lingering disagreement between the two countries snowballed into military exchanges and maneuvers between troops of the two countries in 1993. Before then there had been the killing in 1981 of some Nigerian Navy officers on patrol of the border in Ikang in Cross River State of Nigeria.

Based on the ruling of the International Court of Justice (ICJ), the Bakassi Peninsular has been ceded to Cameroun but there is still an uneasy calm in the area owing to the constant harassment of Nigerian fishermen still living and fishing in the area. Thus, there is still tension and distrust between Nigeria and Cameroun as far as the Bakassi Peninsular is concerned despite the Green Tree Agreement between the two countries on the matter.

However, there had been hay days in the bilateral relations between the two countries. It will be recalled with nostalgia that Cameroun's friendly disposition to Nigeria and her uncompromising stance against Biafra and its collaborators (France, Red Cross Society and other humanitarian organizations) during the Nigerian Civil war (1967 - 1976) forstalled the prolongation and agony of the war. This kind gesture demonstrated by Cameroun to Nigeria under President Ahmadu Ahidjo cannot be forgotten in a hurry by Nigerians. 
Overall, it can be said that Nigeria's immediate neighbours are not habitually hostile to Nigeria notwithstanding minor and isolated cases of boundary skirmishes which in any case have never degenerated into a full scale war with any of the neighbours. Between Nigeria and her immediate neighbours there have been incidents of religious disturbances instigated from outside the country, refugee problems from outside, and the nefarious activities of France in her bid to cut Nigeria to size. But it is instructive for the Nigerian government to realize that the country's cartographic boundary is not coterminous with her security boundary. The latter is bigger than the former. It is for this reason that Nigeria should always be on security alert to counter violation of the country's territorial integrity by any country within or outside her immediate neighbourhood.

It is heartwarming that the conduct of Nigeria's relations with other states has always been guided by the United Nations' recommendation stipulated in Article 33, Subsection 1 of its charter (The UN, 1945) which states that:

Parties to any dispute, the continuation of which is likely to endanger the maintenance of negotiation, inquiry, mediation, conciliation, arbitration, judicial settlement, should report to regional agencies or arrangements or other peaceful norms of their choice.

\section{NIGERIA - CHAD}

The Republic of Chad shares common borders with Libya in the North, Sudan in the East, and the Central African Republic and Cameroun in the South. In the West, Chad is located between Nigeria, Niger Republic, and some parts of Cameroun (James, 1987). Relations between Nigeria and Chad have often times been marred by intermittent border clashes which reached a crescendo in 1983 when there was a fierce military confrontation between the two countries following a surprise and unexpected attack on the Nigerian Army Rifle Company stationed at the outpost of Kainasara and other Islands in Chad by Chadian troops. The attack resulted in the death of nine Nigerian soldiers and the capturing of nineteen Nigerian soldiers as prisoners of war. All of this sprang from the fact that the border between the two countries were not clearly delineated, moreso as there are no evidences in the form of beacons or buoys to make it obvious and incontrovertible (Vogt, 1987a).

The relentless attacks on the Nigerian Security outfits by Chadian troops is informed by Chadian interest in the resources of the lake Chad basin and its environs (James, 1987). Essentially, the incessant border clashes between Nigeria and the Republic of Chad can be explained in the light of the following factors (James, 1987):

(a) Claims and counter - claims over fishing rights in specific portions of the lake Chad basin which have prompted the attacks on Nigerian fishermen by Chadian soldiers and their fishermen;

(b) The unclear boundary lines between the two countries in the lake Chad basin area resulting in spurious territorial claims and conflicts;

(c) The apparent neglect of the lake Chad basin as a result of priority now being given to the lake Chad basin Development Authority which has caused the Nigerian government stupendous amount of money (estimated at 498,000,000.00) so far;

(d) Chad apparently felt humiliated and belittled by the expulsion in January 1983 of about 700,000 "illegal" Chadians from Nigeria by the Nigerian government.

All these went a long way in marring relations between Nigeria and the Republic of Chad. The Chadian civil war between 1978 and 1983 further compounded the frosty relations between the two countries. The war had a spillover effect on Nigeria as thousands of Chadian refugees who fled the theatre of war migrated to Nigeria, thereby overstretching economic and social amenities and facilities in Nigeria. Besides, the militarization of the warning factions in Chad 
with the support of foreign countries, particularly France, Libya, and USA, increased the scope and dimension of the civil war in that country, and this posed grave danger to Nigeria's National Security (James, 1987). The various sophisticated weapons supplied to Chad by France and the USA invariably increased the military capability profile of Chad vis-à-vis Nigeria, thereby making Nigeria vulnerable to Chad at their common borders (Kolodzeij and Harkavy, 1982), and this tended to dim the image and status of Nigeria as the giant of Africa. In 1983, for example, Chadian bandits infiltrated into Nigerian border and attacked and killed Nigerian fishermen around the lake Chad region. Nigerian soldiers at the border engaged the Chadian bandits in a shootout and this prompted the Chadian regular forces to join the fight. All of this underscores the need for the Nigerian government to as soon as possible ensure that the country's borders with the Republic of Chad are clearly delimited and demarcated to forestal any further military exchanges between the two countries, and this will in turn go a long way in helping to promote bilateral relations between the two countries.

On the whole, the two countries see themselves as brothers as evidenced by regular exchange of official visits by top government officials of both countries in recent times. This fact is also illustrated by the fact that Nigeria played a key role in the resolution of the crisis in that country by helping to terminate the involvement of Libya and some extra-African powers, especially France in the crisis, thereby facilitating amicable settlement of the Chadian crisis. Nigeria provided the leadership for the OAU peacekeeping operation in that country, apart from assisting the government of Idriss Derby to crush the rebel uprising in 2007. Many of the rebel leaders including General Felix Maloum who later became the Head of State, were granted asylum in Nigeria.

\section{NIGERIA - EQUATORIAL GUINEA}

Equatorial Guinea, formerly known as Fernandapo, with a population of 777,358 by the last count, is 100 kilometers South-East of Nigerian Coasts. She is nearer to the Coast of Cameroun, and also very close to the Bights of Benin and Biafra (Oshuntokun, 1978a). Bilateral relations between Nigeria and Equatorial Guinea was for a long time, especially in the 1960s and early 1970s, low key. For example, there were clear indications that Equatorial Guinea gave diplomatic, material and logistical support to Biafra during the Nigerian Civil war between 1967 and 1970. The then Nigerian federal government had evidences to support her claim that Equatorial Guinea allowed the Red Cross to ferry food, arms and other materials to the Biafran rebels in addition to also allowing the French government to use the Island as a staging post for supplying military aid, weapons and ammunition to Biafra inspite of Nigerian government protests (Oshuntokun, 1992b). However, on becoming independent on 10 October, 1968, the government of Equatorial Guinea ordered both the Red Cross and the French to leave the country despite their plea to continue their subversive operations. At about the same time, a lot of Nigerians residing in that country were subjected to all manner of inhuman treatments, particularly between 1970 and 1974. The incessant ill treatments of the Nigerians in that country came to a point where the Nigerian government was compelled to evacuate them with the support of merchant navy, gunboats and airforce planes for any eventuality (Oshuntokun, 1992b). Besides, to the dismay of Nigeria, Equatorial Guinea in the 1980s allowed foreigners from outside Africa, such as China and France to enter and settle in that country, a situation considered to be detrimental to Nigeria's national security.

Inspite of all the hostilities to the Nigerians, the Nigerian government restrained herself from annexing and occupying the Island to avoid being accused of interfering in the internal affairs of a weaker nation which would contradict Nigeria's principle of non-interference in the internal affairs of other countries, big or small. 
However, it is dangerous for the Nigerian government to remain lukewarm about the real and potential danger posed to the country's national security in view of the interest shown in that country by some of the great powers of the world. In this regard, Oshuntokun (1978a) had this to say:

In the $19^{\text {th }}$ century, interest in the Island by Great Britain, France, USA, Spain, and Portugal.... When war broke out ( $1^{\text {st }}$ and $2^{\text {nd }}$ world wars) the German government had installed a powerful transmitter on the Island that could send messages to German ships and submarines.

The conspicuous presence of South Africans in the Island in the 1980s, particularly after the abortive coup of 1985 in Nigeria caused a great deal of irritation and uneasiness to the then Nigerian government. Oshuntokun (1992b) described the security implications and the Nigerian government anxiety over this in the following words:

The inkling of the South Africa's presence in Equatorial Guinea come in the wake of the abortive coup d'etat (1985) and the collapse of the (Nigerian) economy. The South Africans initially restrained and were covert in their operations but by the second half of 1986 they were glaringly operating in the open.... With the new situation, the Nigerian government quickly realized the presence posed to Nigeria's security in view of our past neglect of Equatorial Guinea particulary in the 1980s.... On receiving his message about South Africa, the Ambassafor was asked to enquire about the possibility and desirability of any other maneuvers that might be deemed necessary by Equatorial Guinea under a military understanding and cooperation with Nigeria.... The way Nigeria has allowed the relations with Equatorial Guinea to drag on without any purpose is an indictment of our foreign policy which is critically short on forward planning and seriousness.

In the light of the above, and in view of the geo-strategic location of Equatorial Guinea it behooves on the Nigerian government to take a proactive action towards ensuring that Equatorial Guinea is not used by any foreign power to jeopardize Nigeria's national security.

\section{NIGERIA - REPUBLIC OF NIGER}

The Republic of Niger is located in the North-Western part of Nigeria. It is interesting to note that unlike the other Nigeria's immediate neighbours, there has not been any record of any violent border clash between the two countries.

The only issue that has been a cause of concern to the Nigerian government is the influx of Nigerien destitutes into Nigeria through the porous borders and the social and security implications associated with it. The massive migration of Nigerien and Chadian refugees to Nigeria through the Northern highways has turned the highways into a zone of death as deadly weapons such as submachine guns, barretta rifles, bows and arrows are used freely in the zone to kill unsuspecting migrants (Zartmen 1965). However, the Nigerian government in its wisdom has deployed security agencies in the area to undertake joint patrol to check crossborder killings and other criminal activities.

On the whole, one can say without any fear of contradiction that compared to Nigeria's other immediate neighbours, diplomatic relations between Nigeria and the Republic of Niger has over the years been excellent and stable.

\section{EMERGING TRENDS IN NIGERIA'S RELATIONS WITH HER IMMEDIATE NEIGHBOURS}

Nigeria in the New Millennium has made giant strides in terms of strengthening her bilateral and multilateral relations with her immediate neighbours as well as with other countries of the 
world. Indeed, Nigeria's foreign policy has since 1976 when General Murtala Mohammed became head of state gone through various phases under different regimes, and accordingly, the foreign policy posture has at different times been variously described as conservative, moderate, dynamic, and out-rightly aggressive, depending on the tenor and vigour with which the foreign policy objectives have been pursued under different regimes.

On the whole, it can be said that Nigeria's foreign policy is having a new lease of life starting from the military regime of General Ibrahim Babangida when the policy of Economic Diplomacy was introduced as a major foreign policy thrust to make the country's foreign policy to respond to the economic realities in the international environment. Besides, Nigeria even before the emergence of the African Union on 9 July, 2002 had jettisoned her principle of noninterference in the internal affairs of other countries to pave way for genuine interference with the good intention to help restore normalcy in crisis-ridden African countries. Thus, Nigeria made bold to intervene in the volatile situations in both Liberia (between 1989 and 1997) and Sierra Leone (between 1991 and 2002).

Nigeria's multilateral relations has been greatly enhanced under successive federal governments of the country. For example, Nigeria has entered into several mutually beneficial ventures with a good number of countries and has also more forcefully established her presence in the most powerful international organizations in the world, including the United Nations Organisation (UNO), the Commonwealth of Nations, the African Union (AU), and the Economic Community of West African states. Nigeria has been an active member of peace keeping missions in different parts of the world under the auspices of the UN and the OAU (now African Union). Consequent upon all this, Nigeria's image and status as Africa's regional power has continued to soar over the years. This explains why Nigeria has become the first port of call for consultations by foreign powers on any issue that concerns the collective interests of the African peoples.

In summary, the new trends in the re-invigorated Nigeria's foreign policy has the following features:

(i) Significant increase in joint ventures with countries far and near.

(ii) A more visible and active actor in functional cooperation (international organizations) with emphasis on regional integration. Nigeria has been elected into the International Criminal Court, and also into the ECOWAS Court of Justice.

(iii) Much more pragmatic foreign economic policies and defence policies.

(iv) Mutually bilateral and multilateral investment treaties within and outside the West African sub-region.

(v) Regular exchange of state (official) visits among leaders of states.

(vi) Mixed commissions with all immediate neighbours (e.g. Gulf of Guinea Commission, Chad Basin Commission).

(vii) Joint Development Zones.

(viii) Joint Border patrols (as between Nigeria and the Republic of Benin).

(ix) Joint Military Exercise and Training (The National Defence College, Nigeria is open to deserving Army and Police officers from all over the world for military training).

(x) Nigeria has extended Technical Aid Corps to Benin, Niger and Equatorial Guinea to further promote relations with these neighbouring countries.

(xi) Citizen diplomacy designed to protect the lives and properties of Nigerians abroad has been wisely introduced.

(xii) President Mohammed Buhari visited all Nigeria's immediate neighbours in 2015 after his election to extend Nigeria's hands of fellowship to them and to re-assure them of Nigeria's assistance and cooperation in their times of need. 


\section{CRITICAL APPRAISAL OF NIGERIA'S POLICIES TOWARDS HER IMMEDIATE NEIGHBOURS}

Nigeria's friendly disposition to her immediate neighbours is anchored on her avowed policy of good neighbourliness and her recognition of sovereign (legal) equality of all states, big or small. Nigeria is located in the mist of Franco-phone countries that are radically different from her in terms of colonial background and official language, size of population, military and economic strengths. Nigeria's' neighbouring countries are characterized by:

(a) Communal conflicts and civil wards

(b) Fragile state syndrome and crisis of legitimacy

(c) Low income

(d) Relatively small population

(e) Less developed countries

(f) Transborder crimes

(g) Forced migrations (mostly to Nigeria)

(h) Piracy

As a peace loving country, the cool-headed behaviour of Nigeria towards her immediate neighbours even inspite of occasional unwarranted provocations against her is consistent with her big brother posture in the sub-region, sometimes misconstrued as weakness. The incessant encroachment on Nigeria's territory by Cameroun, Benin, and Chad is illustrative of this point. These violations pose serious threats to Nigeria's national security and national pride and integrity. Therefore,

(i) Nigeria should review her policy in this regard with a view to adopting a mixture of stick and carrot in containing the aggressive tendencies of her neighbours since the protection and preservation of a country's territorial integrity is a core national interest of any country.

(ii) The lavish and unnecessary placing of the country's largesse at the disposal of her neighbours at great costs (material and human) and without any element of reciprocity has earned Nigeria the mick name 'father charismas'. Sadly enough, Nigeria's benevolence to other countries does not take cognizance of the fact that the Nigerian masses are suffering from abject poverty, malnutrition and frustration all of which have in some cases resulted in social vices and violent aggression like the case of Boko Haram elements.

(iii) Arising from No (ii) above, it is time for Nigeria to give "Africa is the centre-piece of Nigeria's foreign policy" a hard look. Now that Africa has been completely rid of colonial vestiges and apartheid with the active support of Nigeria, the cornerstone of the country's foreign policy should now be Nigerienism. It would be recalled that Nigeria contributed immensely, diplomatically and materially, towards the granting of independence to Southern Rhodesia (now Zimbabwe) and Angola, and spearheaded the liquidation of apartheid system (1948 - 27 April, 1994) in South Africa. This paved the way for the enthronement of black majority rule in 1994 in that country.

(iv) The largely unmanned Nigeria's common borders with her immediate neighbours poses a serious concern which requires the urgent attention of the federal government. The porous nature of Nigeria's land borders has made it possible for foreign nationals, some of whom are criminals or arm-bearing bandits, to infiltrate into the country to kill innocent people and to fuel religious sentiments and antagonism with disastrous consequences for the peace and unity of the country. Similarly, inadequate protection of the country's maritime borders has given rise to incidents of piracy, illegal oil bunkering, and drug trafficking in the country's territorial waters and economic zones. Deliberate efforts should be made by the 
federal government to check piracy, illegal exploitation of Nigeria's water resources and to also protect the country's coast line against invasion through the seas.

(v) The ECOWAS's policy on free movement of goods and services across national boundaries within the sub-region should be handled with utmost care and diligence. The policy portends to create a leeway for illegal immigrants who enter the country at will and disguise themselves as Nigerian citizens. Therefore, the immigration and customs agencies should be strengthened to conduct meticulous checks at all points of entry into the country to forestall massive migration of destitutes, refugees and criminals into the country.

(vi) Nigeria's attitude towards the ECOWAS Harmonization of Investment Policy in the sub-region is so far half-hearted and lukewarm. As the most naturally endowed country in the sub-region, Nigeria should take the lead in pursuing the policy to its logical conclusion for her own benefit and for the benefit of all member states as the actualization of the policy can serve as a catalyst for the development of the industrial sector in the sub-region.

(vii) Nigeria's characteristic unstable diplomatic relations with her immediate neighbours is unwise, security wise. A foreign power can harp on this situation to launch an attack against Nigeria using a hostile neighbouring country as a military base. It therefore behooves on the federal government to endeavour to maintain cordial relations with all her neighbouring countries. The cooperation of her neighbours could help to fight insurgency. The formation of JTF to jointly fight Boko Haram is illustrative of this point.

\section{THE FUTURE OF NIGERIA'S RELATIONS WITH HER IMMEDIATE NEIGHBOURS}

Nigeria's future relations with her immediate neighbours is very bright. But how far this will be sustained depends largely on the extent to which successive regimes and leaders of the country relate with the successive leaders of the neighbouring countries. Nigeria needs the support of her immediate neighbours to be able to realize her ambitions and aspirations at the world stage, including her ambition to get a permanent seat on the security council of the UN as one of Africa's permanent representatives.

The character and personal idiosyncrasies of a leader have a great impact on the foreign policy of his country. This has given rise to different policies across the world under different regimes and leaders:

Jimmy Carter's human rights policy, especially in Africa; President D'Gualle's policy of No permanent enemy or permanent friend but permanent interest, etc. Nigeria's future foreign policy towards her immediate neigbours will improve with the passage of time if only the country's future leaders appreciate the fact that being friends is better than being enemies.

The nature of internal politics and the dynamics of the country's other domestic factors, such as her economic power, military strength, religious tolerance or intolerance, and unity (as opposed to separation) of the country in the years ahead will progressively impact on the country's relations with her immediate neighbours.

Nigeria's ability to prevail on her Franco-phone neighbours to free themselves from the agelong influence of France will go a long way in bringing about enduring cordial bilateral and diplomatic relations with these countries. This is against the backdrop of the fact that France has been antagonistic to Nigeria since 1962 when Nigeria closed down her embassy in Lagos following her (France's) persistent testing of atomic bombs in the Sahara desert resulting in the death of many North Africans. Similarly, with tact and astute diplomacy, Nigeria should be able to dissuade any of her immediate neighbours from allowing any African country that is not favourably disposed to Nigeria (e.g. South Africa), or an extra-African power (e.g. the USA) 
to establish a military base in a country from where such a country can attack Nigeria. This is particularly important with respect to Equatorial Guinea which is strategically located in the Atlantic Ocean close to Nigeria in the Southern Coast.

\section{SUMMARY AND CONCLUSION}

In the light of the analysis in the preceding pages, it is unequivocally clear that Nigeria has kept faith with her principle of good neighbourliness in her dealings with her immediate and remote neighbours. It is by the virtue of this that she has been able to maintain cordial relations with her neighbours even in the face of unwarranted provocations from the immediate neighbours.

Nigeria has also been able to demonstrate that she is indeed a good neighbour by always taking it upon herself to intercede between warring factions in any of her neighbouring countries to help put an end to crisis situations in any such country. This was aptly demonstrated in the Republic of Chad where she helped to end a five-year civil war. The Joint Task Force (JTF) comprising of the armed forces of Nigeria and that of Cameroun and the Republic of Chad is a clear testimony to the fact that Nigeria's principle of good neighbourliness is appreciated by her immediate neighbours. In addition to this, Cameroun has all these years served as safe heavens for thousands of refugees fleeing from Boko Haram insurgency. This is now being reciprocated by Nigeria which has welcomed thousands of refugees from the English-speaking Southern Cameroun as a result of violent clashes between the national government of Cameroun and the secessionist agitators fighting for a Republic of Ambazonia.

Thus, it is pertinent to conclude on an optimistic note - that in view of Nigeria's characteristic show of magnanimity and spirit of tolerance towards her immediate neighbours, her relations with her neighbours will remain cordial and even blossom in the years ahead.

\section{References}

Muir, R. (1983). Modern Political Geography. Second Edition. London: The Macmillan Press.

Oshuntokun, J. (1978a). "Relations Between Nigeria and Fernado Po (now Equatorial Guinea) from Colonial Times to the Present," (pp.1-9) in A.B. Akinyemi (ed), Nigeria and the World. Nigeria, Ibadan: Oxford University Press.

Osunkokun, J. (1992b). “The Dynamics of Nigeria - Equatorial Guinea Relations from Colonial Times to the Present," (p. 72) in B. Akinterinwa, Nigeria and Its Immediate Neighbours. Constraints and Prospects of SubRegional Security in the 1990's Nigeria. Nigeria Institute of International Affairs (NIIA).

Vogt, M.A. (1987a) "Strategies for the Enhancement of the Security of Nigerian Border." The Eagle Journal of the Nigerian Command and Staff College, Jaji, Nigeria. Special Edition: 39-40.

Zartman, J. W. (1965). "The Politics of Boundaries in North and West Africa”. The Journal of Modern African Studies, $3(2): 155$.

Olusanya, G. and Akindele (1986: p. 2-4), The Fundamentals of Nigeria's Foreign Policy and External Economics Relations in Olusanya, G. and Akindele, R. (eds), Nigeria's External Relations: The First Twenty-Five Years.

The 1999 Constitution of the Federal Republic of Nigeria.

Frankel, J.C. (1973). Contemporary International Theory and the Behaviour of States. Oxford: University Press.

Northedge, F.J. (1968), The International Political System.

The Federal Government of Nigeria, 1996.

The UN, 1945. 